\title{
EFFECT OF DIFFERENT INFILL MATERIAL ON THE SEISMIC BEHAVIOR OF HIGH RISE BUILDING WITH SOFT STOREY
}

\author{
Poonam Patil ${ }^{1}$, D.B.Kulkarni ${ }^{2}$ \\ ${ }^{I}$ Student M. Tech Structure, Rajarambapu Institute of Technology, Islampur \\ ${ }^{2}$ Associate Professor, M.E. Structure, Rajarambapu Institute of Technology, Islampur
}

\begin{abstract}
Many urban multistory buildings in India today have open first storey as an unavoidable feature. This is primarily being adopted to accommodate parking or reception lobbies in the first stories. Also for offices or for any other purpose such as communication hall etc. The construction of reinforced concrete structures with infill wall is a common method of providing shelter to the ever increasing population, where there is seismic activity. In the present work, the effect of different infill materials on the seismic behavior of high rise building with soft stories is studied. For that, G+11 RCC model is selected. Different infill materials like siporex and Laminated glass are used. Different cases considering different location of soft stories are considered for the analysis. To study the effect of different infill material on high rise structure, linear dynamic analysis (Response spectrum analysis) in software ETABs is carried out. Seismic parameters like time period, base shear, storey displacement and storey drift are checked out
\end{abstract}

Keywords: soft storey, infill material, response spectrum method, ETABs ****

\section{INTRODUCTION}

The tremendous pace of urbanization of rural areas and ever increasing population in urban areas has necessitated the increase in the construction of multistoried buildings. Many such buildings constructed in recent times have a special feature - the ground storey is left open for the purpose of parking i.e. columns in the ground storey do not have any partition walls (of either masonry or RC) between them. Such buildings are often called open ground storey buildings or buildings on stilts. The relatively flexible in the ground storey or the relative horizontal displacement it undergoes in the ground storey is much larger than the above stories, this flexible ground storey is called soft storey

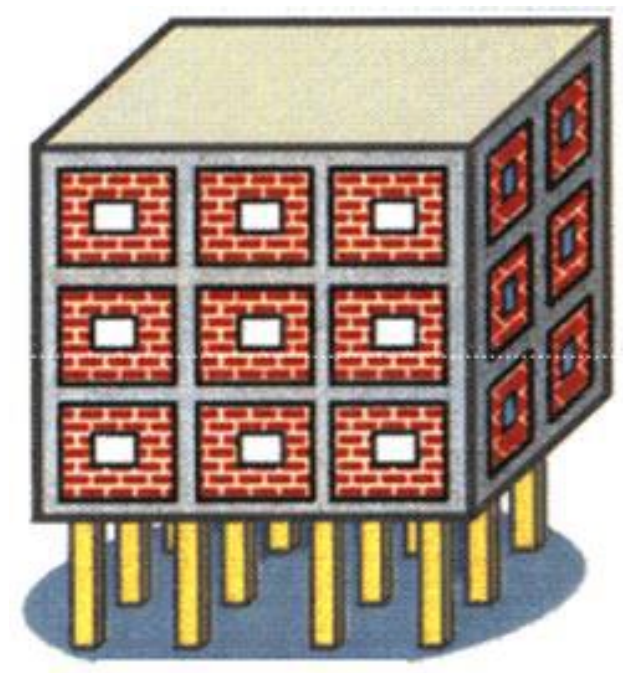

Fig. 1.1 Building with soft storey

\subsection{Infilled Frames}

The infilled frame, a structure combining the frame with the infill within the frame, has better lateral resistance potential and therefore, attracted the investigator's attention since the fifties of the present century It has been appreciated that the addition of walls and floors impart considerable extra strength to a frame building. The walls may act as vertical bracing to transfer the lateral loads to the ground while the floors provide horizontal bracing to transfer the lateral loads from unbraced to braced vertical bents without any consideration of their strength. The result of infilling the frame by means of masonry wall is a structure combining the rigidity of the infill frame with the containment of the frame which restrains the frame from disintegrating after cracking. An additional benefit which is immediately apparent is a resulting in plane stiffness greater than the sum of the separate stiffness of the frame and the infill.

\section{ANALYTICAL WORK}

Response spectrum method is used for the analysis of structure. A G+11 storey building with RC moment resisting frame with different cases of soft storey chosen for this study. Different infill materials are used to study the effect of infill. The presence of infill affects the distribution of lateral load in the frames of building because of the increase of stiffness of frames. The study of interaction of infill with frames has been attempted by using Equivalent diagonal strut method.

\subsection{Equivalent Diagonal Strut Method}

The geometric and material properties of the equivalent diagonal strut are required for conventional braced frame analysis. The geometric properties are of effective width and 
thickness of the strut. The thickness and material properties of strut are similar to the infill wall.

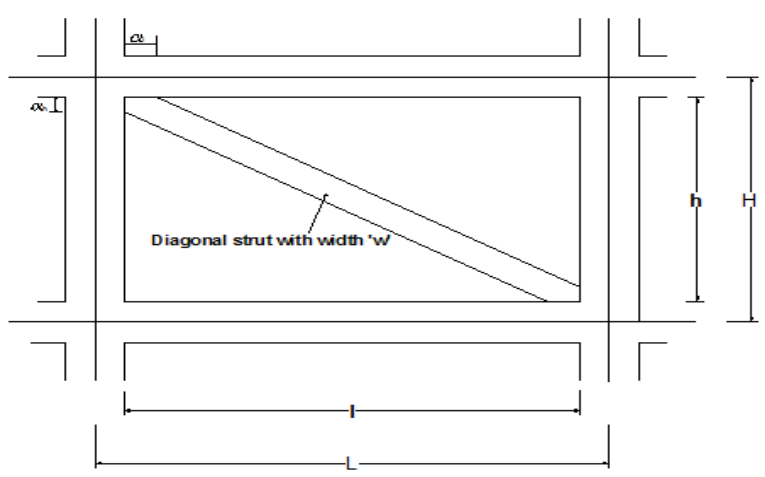

Fig.1.2 Diagonal strut

Many investigators have proposed various approximations for the width of equivalent diagonal strut. Originally proposed by Polyakov (1965) and subsequently developed by many investigators, the width of strut depends on the length of contact between the wall and the columns, $\alpha_{\mathrm{h}}$, and between the wall and beams, $\alpha_{\mathrm{L}}$. Stafford Smith (1996) developed the formulations for $\alpha_{\mathrm{h}}, \alpha_{\mathrm{L}}$.

Following equations are proposed to determine for the calculation of width of diagonal strut

$$
\begin{aligned}
& \alpha_{h}=\frac{\pi}{2}\left(\frac{E_{f} I_{c} h}{2 E_{m} \sin 2 \theta}\right)^{\frac{1}{4}} \\
& \alpha_{L}=\pi\left[\frac{E_{f} I_{h} L}{2 E_{m} \sin 2 \theta}\right]^{\frac{1}{4}} \\
& w=\frac{1}{2} \sqrt{\alpha_{h}^{2}+\alpha_{L}^{2}}
\end{aligned}
$$

Whereas,

Em $=$ Elastic modulus of masonary wall,

$\mathrm{Ef}=$ Elastic modulus of frame material

$\mathrm{t}=$ thickness of infill wall,

$\mathrm{h}=$ height of infill wall

$\mathrm{L}=$ length of infill wall,

$I_{c}=$ moment of inertia of column

$\mathrm{I}_{\mathrm{b}}=$ moment of inertia of beam,

$\mathrm{w}$ = width of diagonal strut

\subsection{Types of Cases used for Analysis of Structure}

There are five different cases considered to analyze 12storey $(\mathrm{G}+11)$ structure so that proper provision of soft storey can be predicted.

1) Building has full Infill material masonary wall in all stories

2) Building has soft storey at ground level and below plinth level

3) Building has soft storey at third floor

4) Building has soft storey at sixth floor

5) Building has soft storey at sixth floor

Following figures shows the model of different cases done in ETABS software.
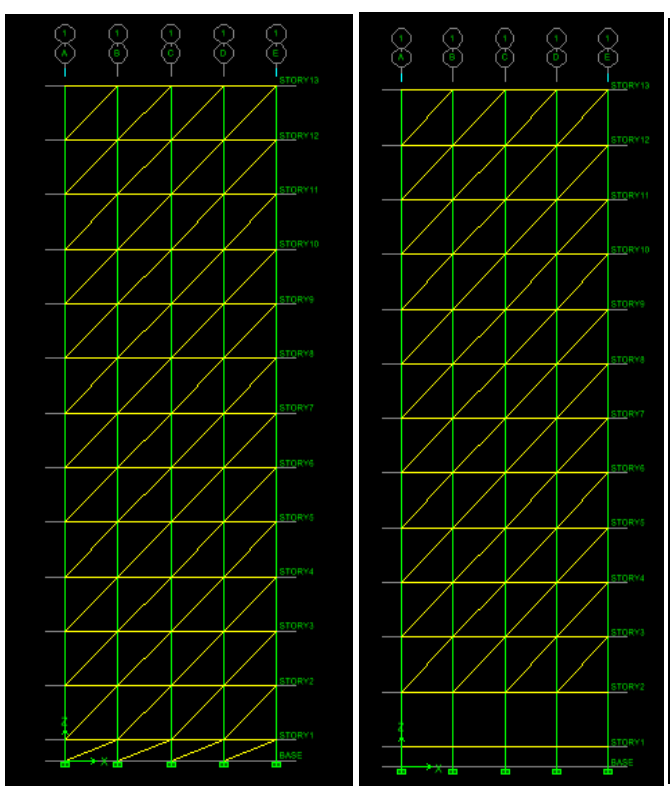

Fig.1.3 Full infill model
Fig.1.4 Soft storey at ground floor

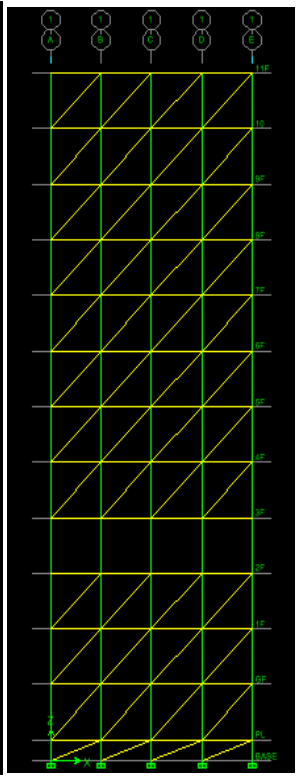

Fig.1.5 Soft storey at third floor

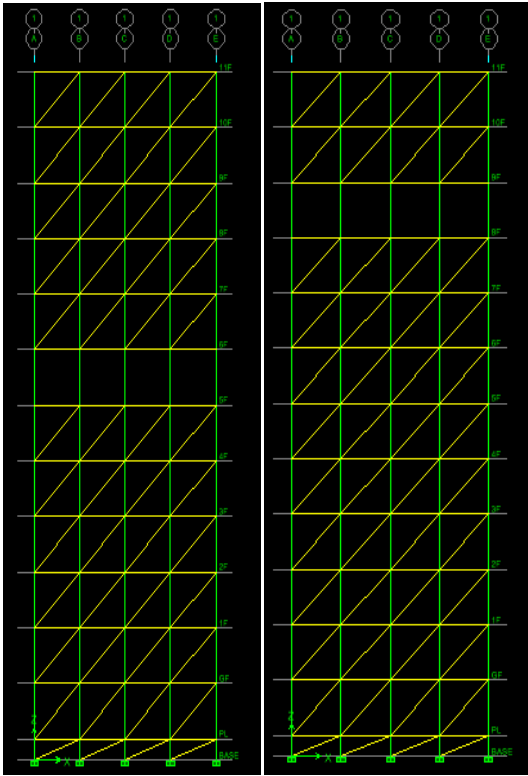

Fig.1.5 Soft storey Fig.1.5 Soft storey sixth floor ninth floor 


\subsection{Structural Data}

Table 1.1 Details of structural data

\begin{tabular}{|l|l|}
\hline Type of structure & Residential $(\mathrm{G}+11)$ \\
\hline Zone & III \\
\hline Foundation level to Ground floor height & $1.5 \mathrm{M}$ \\
\hline Floor to floor height & $3 \mathrm{M}$ \\
\hline Wall thickness & $230 \mathrm{MM}$ \\
\hline Thickness of slab & $140 \mathrm{MM}$ \\
\hline Live load & $2 \mathrm{KN} / \mathrm{m}^{2}$ \\
\hline Floor finish & $1 \mathrm{KN} / \mathrm{m}^{2}$ \\
& \multicolumn{2}{|l|}{$300 X 500 \mathrm{~mm}$} \\
\hline Beam sizes & $1) \quad 300 X 400 \mathrm{~mm}$ \\
\hline Column sizes & $2)$ \\
& $1) \quad 300 X 700 \mathrm{~mm}$ \\
\hline Infill material used & $2) \quad$ 1) Siporex \\
& $2)$ Laminated Glass \\
\hline
\end{tabular}

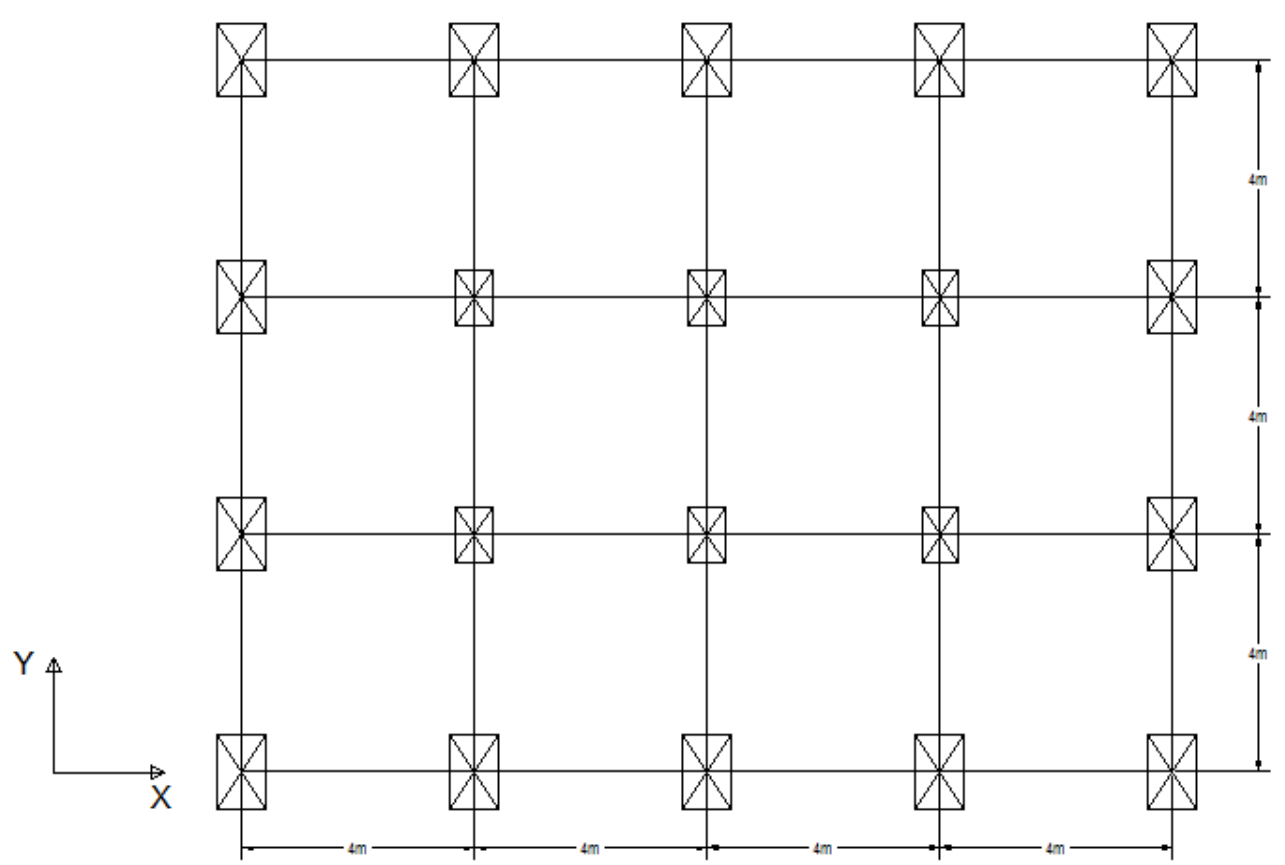

Fig.1.6 Typical plan of model considered in study

\section{RESULTS AND DISCUSSION}

The Results of analysis of multistorey building with soft storey obtained from Etabs software are tabulated below

\subsection{Time Period of Different Infill Material}

Time period of different infill material with different soft storey positions is presented in table 1.2. The graphical representation is also shown in fig 1.7.

Table 1.2 Time period (sec) of different infill material

\begin{tabular}{|l|l|l|l|l|l|}
\hline Infill Material & Model I & Model II & Model III & Model IV & Model V \\
\hline Siporex infill & 1.3834 & 2.1534 & 1.9282 & 1.6680 & 1.4336 \\
\hline Laminated Glass & 1.0489 & 1.851 & 1.592 & 1.3843 & 1.1136 \\
\hline
\end{tabular}




\section{Time Period (sec) graph}

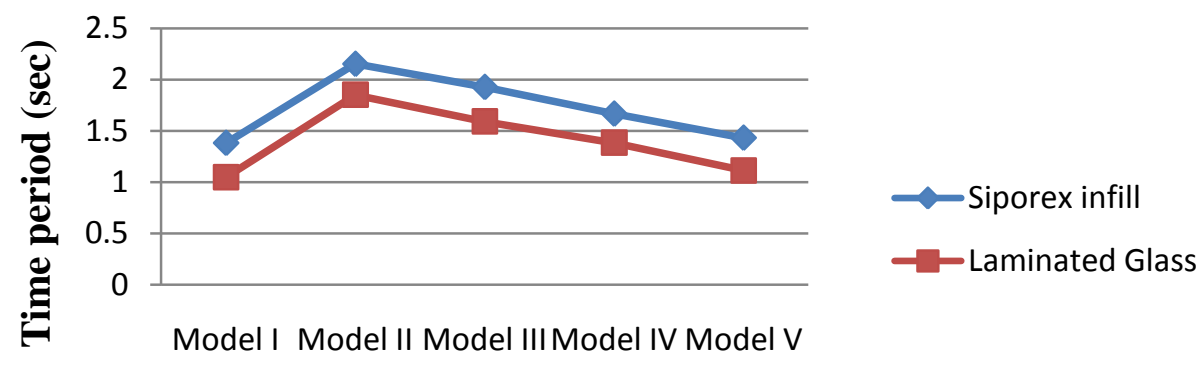

Floor No.

Fig. 1.7 Time period graph for Siporex and Laminated Glass material

\subsection{Base Shear of Different Infill Material}

Base shear of different infill material with different soft storey positions is presented in table 1.3. The graphical representation is also shown in fig 1.8 .

Table 1.3 Base shear (KN) of different infill material

\begin{tabular}{|l|l|l|l|l|l|}
\hline Base Shear (KN) & Model I & Model II & Model III & Model IV & Model V \\
\hline Siporex & 983.93 & 973.26 & 1012.06 & 975.57 & 975.97 \\
\hline Laminated glass & 776.54 & 776.62 & 779.14 & 780.39 & 779.68 \\
\hline
\end{tabular}

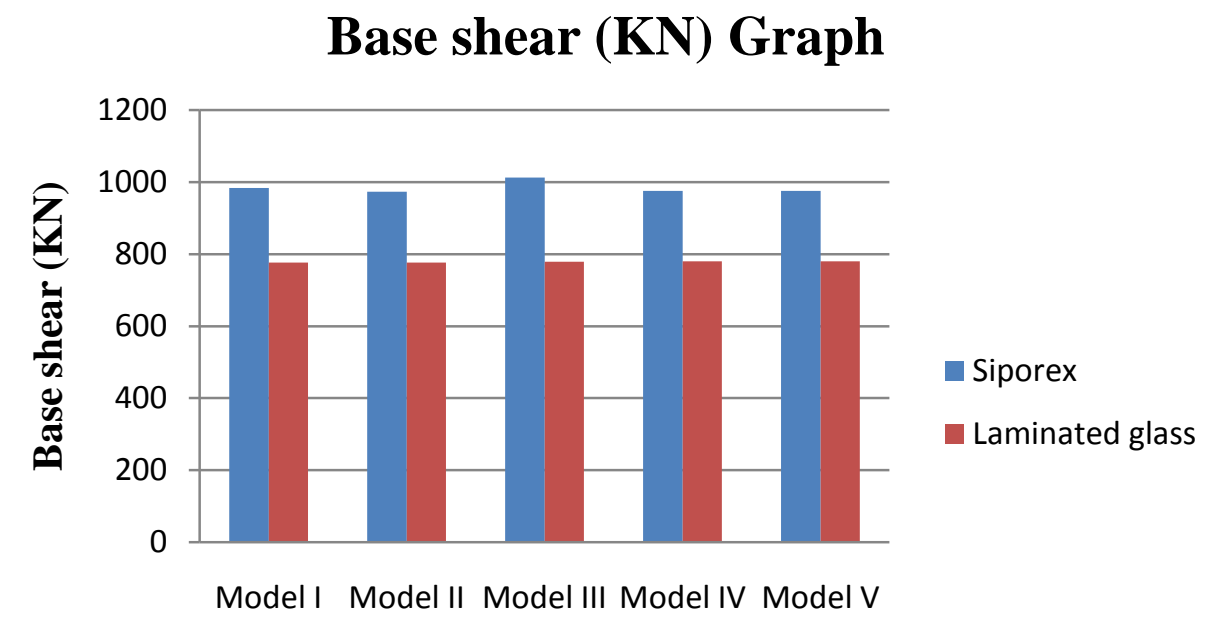

Floor No.

Fig.1.8 Base shear graph for Siporex and Laminated Glass material

\subsection{Storey Displacement of Different Infill Material}

Storey displacement of different infill material with different soft storey positions is presented in following table. Storey displacement of siporex and laminated glass material is presented in table 1.4 and table 1.5 respectively. The graphical representation is also shown in fig 1.9 and fig 1.10 . 


\subsubsection{Story Displacement of Siporex Infill Model}

Table 1.4 Story displacement (M) of Siporex infill

\begin{tabular}{|l|l|l|l|l|l|}
\hline Storey No. & Model I & Model II & Model III & Model IV & Model V \\
\hline $11 \mathrm{~F}$ & 0.0229 & 0.0489 & 0.0469 & 0.0423 & 0.0351 \\
\hline $10 \mathrm{~F}$ & 0.0217 & 0.0476 & 0.0456 & 0.041 & 0.0338 \\
\hline $9 \mathrm{~F}$ & 0.0201 & 0.046 & 0.044 & 0.0394 & 0.0321 \\
\hline $8 \mathrm{~F}$ & 0.0183 & 0.0443 & 0.0421 & 0.0377 & 0.0183 \\
\hline $7 \mathrm{~F}$ & 0.0164 & 0.0423 & 0.0401 & 0.0357 & 0.0162 \\
\hline $6 \mathrm{~F}$ & 0.0143 & 0.0403 & 0.038 & 0.0335 & 0.0142 \\
\hline $5 \mathrm{~F}$ & 0.0122 & 0.0382 & 0.0358 & 0.0123 & 0.0121 \\
\hline $4 \mathrm{~F}$ & 0.01 & 0.0361 & 0.0336 & 0.01 & 0.01 \\
\hline $3 \mathrm{~F}$ & 0.0079 & 0.034 & 0.0311 & 0.0079 & 0.0078 \\
\hline $2 \mathrm{~F}$ & 0.0059 & 0.0319 & 0.0063 & 0.0058 & 0.0058 \\
\hline $1 \mathrm{~F}$ & 0.0039 & 0.0300 & 0.004 & 0.0039 & 0.0039 \\
\hline GF & 0.0021 & 0.0280 & 0.0022 & 0.0021 & 0.0021 \\
\hline BASE & 0.0004 & 0.0027 & 0.0005 & 0.0004 & 0.0004 \\
\hline
\end{tabular}

\section{Storey disp (M) graph}

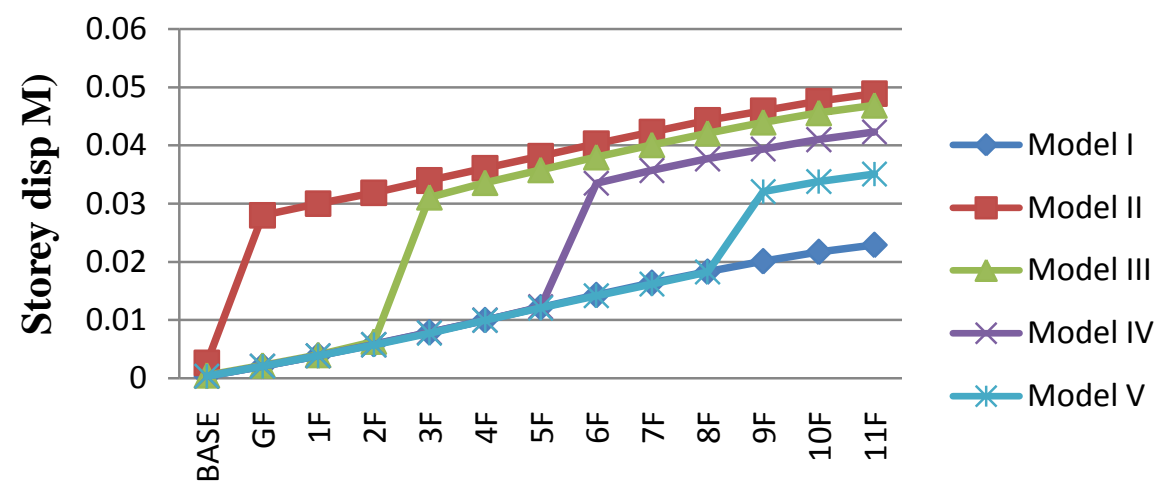

Floor

Fig. 1.9 Storey displacement graph for Siporex infill

\subsubsection{Story Displacement of Laminated Glass Infill Model}

Table 1.5 Story displacement (M) of Laminated Glass infill

\begin{tabular}{|l|l|l|l|l|l|}
\hline Storey No & Model I & Model II & Model III & Model IV & Model V \\
\hline $11 \mathrm{~F}$ & 0.0133 & 0.0348 & 0.0314 & 0.029 & 0.0233 \\
\hline $10 \mathrm{~F}$ & 0.0124 & 0.0339 & 0.0305 & 0.0281 & 0.0224 \\
\hline $9 \mathrm{~F}$ & 0.0114 & 0.0328 & 0.0294 & 0.0271 & 0.0213 \\
\hline $8 \mathrm{~F}$ & 0.0103 & 0.0317 & 0.0283 & 0.0259 & 0.0103 \\
\hline $7 \mathrm{~F}$ & 0.0091 & 0.0305 & 0.0271 & 0.0248 & 0.0091 \\
\hline $6 \mathrm{~F}$ & 0.0078 & 0.0293 & 0.0259 & 0.0234 & 0.0078 \\
\hline $5 \mathrm{~F}$ & 0.0066 & 0.028 & 0.0246 & 0.0067 & 0.0066 \\
\hline $4 \mathrm{~F}$ & 0.0053 & 0.0268 & 0.0234 & 0.0053 & 0.0053 \\
\hline $3 \mathrm{~F}$ & 0.0042 & 0.0256 & 0.0221 & 0.0041 & 0.0041 \\
\hline $2 \mathrm{~F}$ & 0.003 & 0.0244 & 0.0031 & 0.003 & 0.003 \\
\hline $1 \mathrm{~F}$ & 0.002 & 0.0234 & 0.002 & 0.002 & 0.002 \\
\hline GF & 0.001 & 0.0224 & 0.001 & 0.001 & 0.001 \\
\hline PL & 0.0002 & 0.0022 & 0.0002 & 0.0002 & 0.0002 \\
\hline
\end{tabular}




\section{Storey disp (M) graph}

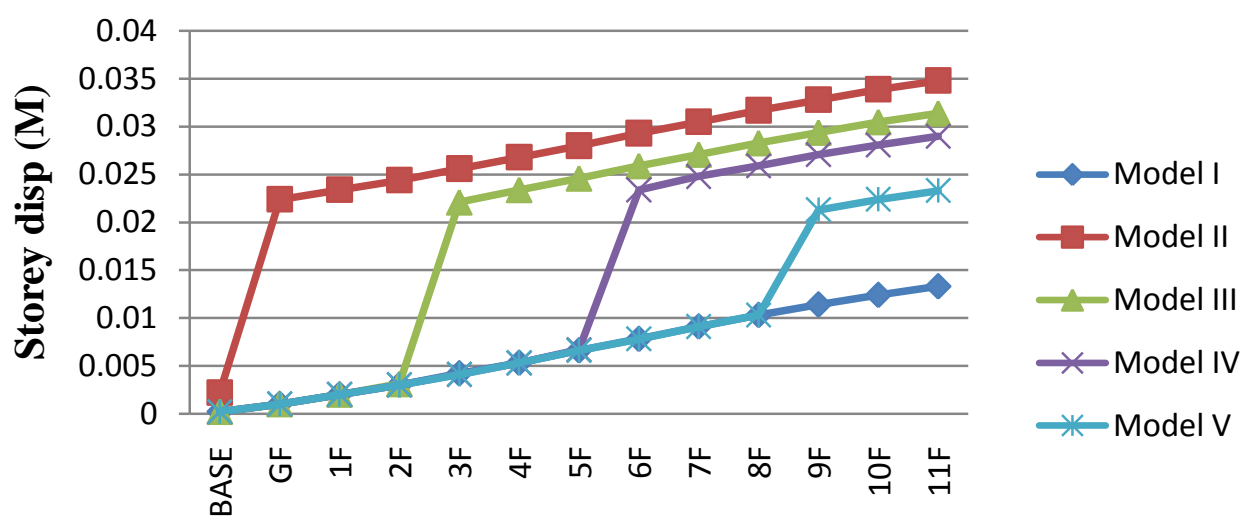

Floor No.

Fig.1.10 Storey displacement graph for Laminated Glass infill

\subsection{Storey Drift of Different Infill Material}

Storey drift of different infill material with different soft storey positions is presented in following table. Storey drift of siporex and laminated glass material is presented in table
1.6 and table 1.7 respectively. The graphical representation is also shown in fig 1.11 and fig 1.12

\subsubsection{Story Drift of Siporex Infill Model}

Table 1.6 Story drift of Siporex infill

\begin{tabular}{|l|l|l|l|l|l|}
\hline Storey No & Model I & Model II & Model III & Model IV & Model V \\
\hline $11 \mathrm{~F}$ & 0.000418 & 0.000323 & 0.000337 & 0.000326 & 0.000323 \\
\hline $10 \mathrm{~F}$ & 0.000486 & 0.000391 & 0.000408 & 0.000394 & 0.000428 \\
\hline $9 \mathrm{~F}$ & 0.000544 & 0.000445 & 0.000464 & 0.00045 & 0.003459 \\
\hline $8 \mathrm{~F}$ & 0.000587 & 0.000486 & 0.000507 & 0.000486 & 0.000518 \\
\hline $7 \mathrm{~F}$ & 0.000617 & 0.000513 & 0.000535 & 0.000569 & 0.00051 \\
\hline $6 \mathrm{~F}$ & 0.000634 & 0.000527 & 0.00055 & 0.005298 & 0.000528 \\
\hline $5 \mathrm{~F}$ & 0.000638 & 0.000534 & 0.000553 & 0.000586 & 0.000535 \\
\hline $4 \mathrm{~F}$ & 0.000629 & 0.000532 & 0.000613 & 0.000529 & 0.000532 \\
\hline $3 \mathrm{~F}$ & 0.000608 & 0.000519 & 0.006227 & 0.000521 & 0.00052 \\
\hline $2 \mathrm{~F}$ & 0.000577 & 0.000492 & 0.000575 & 0.000498 & 0.000498 \\
\hline $1 \mathrm{~F}$ & 0.000536 & 0.000525 & 0.00048 & 0.000468 & 0.000467 \\
\hline GF & 0.000478 & 0.006331 & 0.000448 & 0.000431 & 0.000431 \\
\hline BASE & 0.000248 & 0.001791 & 0.000317 & 0.000306 & 0.000306 \\
\hline
\end{tabular}




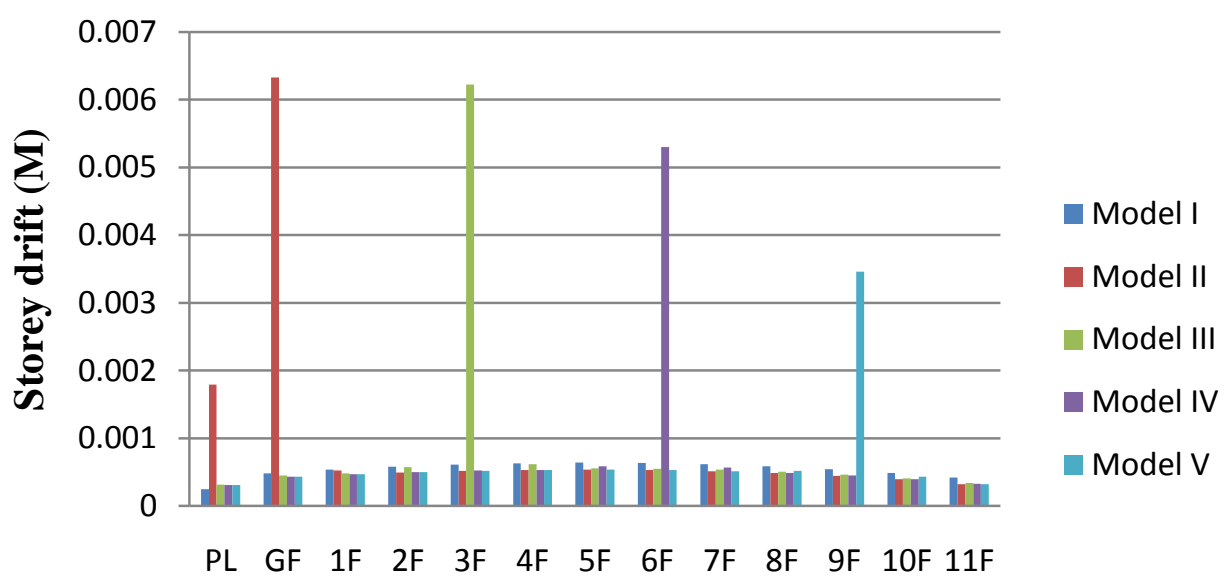

Floor

Fig 1.11 Storey drift graph for Siporex infill

\subsubsection{Story Drift of Laminated Glasss Infill Model}

Table 1.7 Story drift of Laminated Glass infill

\begin{tabular}{|l|l|l|l|l|l|}
\hline Storey No & Model I & Model II & Model III & Model IV & Model V \\
\hline $11 \mathrm{~F}$ & 0.000227 & 0.000228 & 0.000227 & 0.000228 & 0.000226 \\
\hline $10 \mathrm{~F}$ & 0.000259 & 0.000259 & 0.000259 & 0.000259 & 0.000274 \\
\hline $9 \mathrm{~F}$ & 0.000284 & 0.000285 & 0.000284 & 0.000285 & 0.002746 \\
\hline $8 \mathrm{~F}$ & 0.000303 & 0.000304 & 0.000303 & 0.000301 & 0.000318 \\
\hline $7 \mathrm{~F}$ & 0.000316 & 0.000316 & 0.000316 & 0.00034 & 0.000314 \\
\hline $6 \mathrm{~F}$ & 0.000322 & 0.000322 & 0.000322 & 0.004194 & 0.000322 \\
\hline $5 \mathrm{~F}$ & 0.000321 & 0.000322 & 0.000319 & 0.000345 & 0.000321 \\
\hline $4 \mathrm{~F}$ & 0.000315 & 0.000315 & 0.000343 & 0.000313 & 0.000314 \\
\hline $3 \mathrm{~F}$ & 0.000302 & 0.000303 & 0.004758 & 0.000302 & 0.000302 \\
\hline $2 \mathrm{~F}$ & 0.000284 & 0.000282 & 0.000311 & 0.000283 & 0.000283 \\
\hline $1 \mathrm{~F}$ & 0.00026 & 0.000289 & 0.000257 & 0.00026 & 0.00026 \\
\hline GF & 0.000231 & 0.005058 & 0.000232 & 0.000231 & 0.000231 \\
\hline PL & 0.000161 & 0.001435 & 0.00016 & 0.00016 & 0.00016 \\
\hline
\end{tabular}

Storey drift Graph

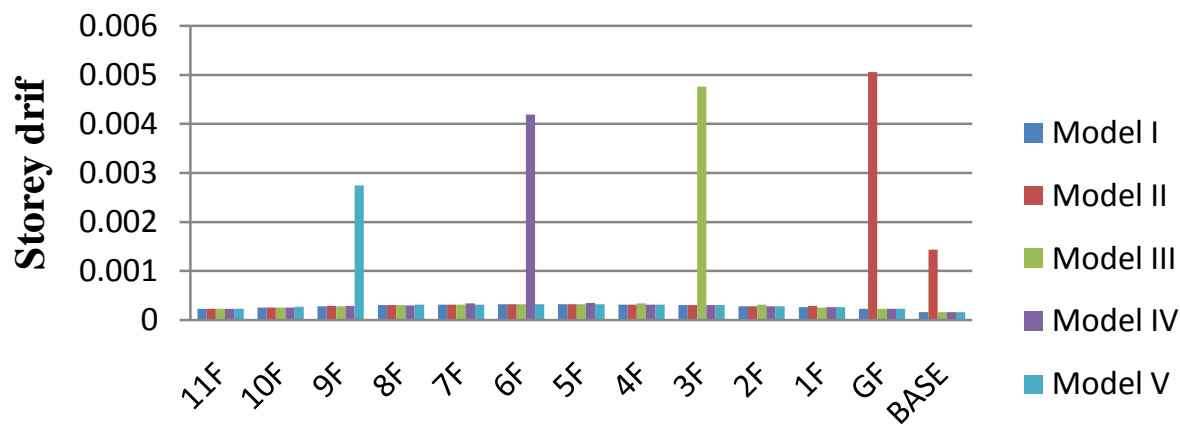

Floor No.

Fig 1.12 Storey drift graph for concrete infill 


\section{CONCLUSION}

The study is based on finding and comparing time period, base shear, Storey displacement and storey drift parameters of building consisting of soft storey.

1. Time period of siporex infill is $24.17 \%$ more than Laminated glass infill material.

2. Base shear is maximum for case I. And it is maximum for siporex material. As base shear is mainly depends upon weight of structure, different positions of soft storey levels do not show significant effect on base shear.

3. Storey displacement is uniformly increasing when infill material is provided for all the floors. From two different infill materials, storey displacement of siporex material is $28.33 \%$ more than brick infill material for Case II and 33.04\%. 31.44\%,33.62\% more for case III, IV, V respectively.

4. The values of storey drift for all the stories are found to be within the permissible limit i.e. not more than 0.004 times to storey height according to IS 1893 : 2002 (Part I)

\section{REFERENCES}

[1] A.S.Kasnale, Dr. S.S.Jamkar, "Study Of Seismic Performance For Soft Basement Of RC Framed", International Journal of Engineering Research Technology ( IJERT), Jan 2013

[2] Dande P. S. , Kodag P. B., " Influence of Provision of Soft Storey in RC Frame Building for Earthquake Resi stance Design", International Journal of Engineering Research and Applications (IJERA) ,Vol. 3, Issue 2, March -April 2013, pp.461-468

[3] F. Demir and M. Sivri "Earthquake Response of Masonry Infilled Frames" ECAS2002 International Symposium on Structural and Earthquake Engineering, October 14, 2002, Middle East Technical University, Ankara, Turkey

[4] Ganga Tepugade and Suchita Hirde, " Seismic performance of multistory building with soft storey at different level with RC shear wall", International Journal of Current Engineeering And Technology, Vol 4,Jun 2014

[5] Hiten L. Kheni, Anuj K. Chandiwala, "Seismic Response of RC Building with Soft Stories" ,International Journal of Engineering Trends and Technology

[6] (IJETT) -Volume 10, Number 12 - Apr 2014,Page 565

[7] M. N. Fardis and T. B. Panagiotakos "Seismic Design and Response of Bare and Masonry-Infilled Reinforced Concrete Buildings" Journal of Earthquake Engineering, 1:3, pp.475-503, 2002.

[8] Muang, S., "Seismic behaviors of reinforced concrete structures with soft Story", Proceedings of the $3^{\text {rd }}$ International Conference on Structural Stability and Dynamics, June 19-22, 2005, Kissimmee, Florida.

[9] Madan, A., Reinhorn, A. M., Mander, J. B. and Valles, R. E., "Modeling of Masonry Infill Panels For Structural Analysis." ASCE Journal of Structural
Engineering, Vol. 123, No. 10, October, 2007, pp. 1295-1297.

[10] P.B.Lamb, Dr R.S. Londhe, "Seismic Behavior of Soft First Storey", IOSR Journal of Mechanical and Civil Engineering (IOSR-JMCE), Volume 4, Issue 5 (Nov. Dec. 2012), PP 28-33

[11] Sivakumar, S. Karthik, et al , "Seismic Vulnerability of Open Ground Floor Columns in Multi Storey Buildings", International Journal of Scientific Engineering and Research (IJSER), Volume 1 Issue 3, November 2013 